\title{
Editorial
}

\section{The Importance of Natural History and The Canadian Field-Naturalist to Natural Science}

The discipline of Natural History spans hundreds of years. As a formal discipline, its roots can be traced back to the $18^{\text {th }}$ century Age of Enlightenment (Mayr 1982), and it has spawned a plethora of natural science disciplines, such as geology, palaeontology, biology, ecology, ethology, systematics, and genetics (Arnold 2003). As a practice, however, it has existed since the dawn of humans. Indeed, the very survival of early humans depended on their prowess as naturalists (Fleischner 2005).

So, what precisely is natural history? Definitions vary (Sears 1944; Greene and Losos 1988; Bates 1990; Green 1994; Wilcove and Eisner 2000), but most are based on the notion of direct field observation of living organisms in their environment. Wilcove and Eisner (2000) define natural history as "the close observation of organisms - their origins, their evolution, their behaviour, and their relationships with other species."

The role of natural history as the foundation of good ecological investigation rather than the simple, antiquated musings on nature is understated in the literature and inadequately recognized among scientists in many of the disciplines (ironically) spawned by natural history. Some have argued that the heyday of natural history has passed; that other, more quantitative disciplines, such as ecology and molecular biology, have eclipsed natural history (Peters 1980). The reasons for this are varied, not the least of which is that new generations of scientists naturally migrate to avantgarde developments in their fields (Arnold 2003). Lopez (2001) captured another element of the estrangement: "Firsthand knowledge is enormously time consuming to acquire; with its dallying and lack of end points, it is also out of phase with the short-term demands of modern life." Emerging scientists faced with demands imposed by academic institutions in the fast-paced world of on-line publishing could easily eschew natural history in favour of other, more efficient and "marketable" means of acquiring data.

In response to the marginalizing of natural history by quantitative ecologists, the rebranding terminology of 'scientific naturalist' (Futuyama 1998) was crafted to propose a counter-argument. Moreover, Arnold (2003) noted that: "equations and computer simulation can be powerful weapons in the arsenal of the naturalist." I submit that the corollary is also true: natural history is a powerful weapon in the arsenal of the quantitative ecologist. Natural history, practiced in its raw, descriptive state by professionals and amateurs alike, provides real value to other disciplines of natural science, regardless of whether or not the work is pub- lished as a stand-alone or incorporated into quantitative analyses.

The collateral damage of the retreat from natural history by other disciplines includes liquidation of natural history collections and dismantling of natural history-oriented curricula within many academic institutions in North America (Noss 1996; Futuyma 1998; Schmidley 2005). The upshot is that field training for undergraduates in most North American Universities is impoverished. One bizarre outcome is that in the absence of in-house expertise, self-taught field naturalists have had to be hired by Canadian universities to provide organism identifications in support of post-graduate field-based studies. The few exceptions offering natural history training include Texas A\&M University, Texas Tech University, Evergreen State University, Fort Hayes State University, and University of Vermont (Schmidley 2005) as well as McGill University

In addition to the degraded quality of natural history training in universities, young children have become increasingly alienated from nature. Whereas children of up to a generation ago received early naturalist training simply as a consequence of the parental mantra 'go outside and play', children today are less exposed to nature due to overprotective parental and community instincts and the omnipotent electronic world. Consequently, children are thrust into a highly-scheduled existence that includes precious little time to explore the world around them. Exposure to nature is the spark that ignites a passion among children with naturalistic intelligence (Gardner 1999). Fortunately, awareness of the pandemic alienation of children from nature is reaching mainstream, and has spawned a movement to remedy effects of the 'nature deficit syndrome' (Louv 2005). It should be noted that organizations such as The Ottawa Field-Naturalists' Club have, and continue to provide excellent training opportunities for naturalists of all ages.

It is ironic that at a time of declining field-based natural history training in North America, our need for highly-skilled field naturalists is greater than ever (Bartholomew 1986; Noss 1996; Dayton and Sala 2001). As habitats and species become increasingly threatened by the unprecedented pace of land-use intensity; as climate change spearheads shifting ranges of species and ecosystems, we will need to have a depth of understanding of species, their taxonomy, habitat requirements, biogeography, and response to anthropogenic threats. As Bartholomew (1986) put it: "knowing natural history allows an investigator to phrase questions with precision." 
As an anecdote to the division between natural history and other related disciplines, Bury (2006) advised that: "We need to merge the best natural history, field ecological data, and biological questions with the latest advances in other fields of inquiry if we are to advance science and solve key environmental issues." Publications such as The Canadian Field-Naturalist (CFN) provide an important role in disseminating raw natural history information as well as merging various disciplines for the benefit of greater scientific understanding of the natural world. Moreover, published natural sciences data ages well. Unlike physical sciences data, which may become immaterial within a few years, credibly documented natural history data maintains its value. Given that baseline data is critically important to measuring change, one could argue that it increases in value with the passage of time. Natural History documentation from the $19^{\text {th }}$ and $20^{\text {th }}$ Century is regularly referenced in the execution of $21^{\text {st }}$ Century natural sciences. As such, it holds a key place in the broader scientific community.

Despite the peaks and troughs in popularity of natural history, The Canadian Field-Naturalist has maintained one of the world's longest traditions of publishing natural history for professionals and amateurs. This issue marks the $125^{\text {th }}$ volume of publication (an unbroken production that, with the CFN's predecessors, extends back over 130 years (Brunton 1986; Brunton 2004). This record is astounding and unmatched by any comparable Canadian publication. All the more impressive considering that it is published independently and solely with the support of subscribers and the membership of The Ottawa Field-Naturalists' Club. That remarkable production was substantially assisted in the last decade by proceeds from the generous bequest of former Ottawa Field-Naturalists' Club Honorary Member Thomas Manning (Halliday 2002, Carter 2004).

The team behind this feat deserves note. As the longest-serving Editor of the CFN, Francis Cook has experienced the widening rift between natural history and other disciplines. He has also experienced peaks and troughs of support for his beloved journal, of which he has been a tenacious defender. Francis has also proven to be magnanimous as a mentor of young scientists and amateur naturalists and has amassed a vast network of contacts and correspondents within the natural history world. I am certain that many of you, as you read this, will recall submitting your first paper to Francis during his tenure as Editor of the CFN. Throughout his 34 years as Editor, Francis continued to practice the craft and science of natural history. His expertise as a herpetologist spans far and wide. Moreover, Francis built up an impressive team of Associate Editors who are fellow practitioners of natural history. The fact that almost all Associate Editors have continued with The Canadian Field-Naturalist past the tenure of Francis Cook is a testament to his dedication to maintaining a high quality journal of natural history.
I am pleased that Francis will continue to serve the journal as Associate Editor. I also welcome Tom Jung and Claude Renaud as our newest Associate Editors, and Trina Rytwinski as our new Assistant Editor.

I am honoured to have been selected to be the new editor of The Canadian Field-Naturalist. It is a position I take with great pride in the journal and in the practice of natural history. Among the many scientific journals that I read professionally, The Canadian FieldNaturalist holds the greatest interest for me. I consistently read more articles in the CFN than in other journals. I believe in the important role the journal plays in disseminating natural history as well as in the development of the naturalist community, both professional and amateur.

I am grateful for the support of The Ottawa FieldNaturalists' Club Council and the oversight of the Publications Committee. The high quality of the journal would not be possible without the magnificent talents of Liz Morton, Copy-Editor, Wendy Cotie, Typesetter, Leslie Cody, Indexing, Roy John, Book Review Editor, Frank Pope, Business Manager, Jay Fitzsimmons, Incoming Journal Manager, Sandy Garland, Webmaster, and Jim Ward, who kept the operation running for many years. Chuck Graham of Gilmore Printers provides printing services, and mailing services are provided by Donna Morin of the BMR Group. We thank the contributors for their hard work and the dedication of reviewers, who practice and believe in the peer review system.

We are making every effort to get the journal up to date and published in a timely manner. Great strides in that regard have been achieved in the last year. To maintain this going forward, we have made several changes, not the least of which is to adopt the Open Journal System of on-line publishing. Jay Fitzsimmons reports in this issue on the specifics of the on-line publishing changes we are making to improve efficiency. I am pleased to report that all back issues of The Canadian Field-Naturalist from Volume 33 - 120 are now available via the Biodiversity Heritage Library. These issues can be accessed via our website www. ofnc.ca.

It is my hope that we continue publishing this journal independently. Dear readers, enjoy this issue and continue to practice the craft and science of natural history in the tradition of Linnaeus, Darwin, Wallace, Buffon, Macoun, Fletcher, Taverner, Leopold, Schindler, and all of the great naturalist trailblazers.

\section{CAROLYN CALLAGHAN}

\section{Literature Cited}

Arnold, S. J. 2003. Anniversary essay: Too much natural history, or too little? Animal Behavior 65: 1065-1068.

Bartholomew, G. A. 1986. The role of natural history in contemporary biology. Bioscience 36: 324-329.

Bates M. 1990. The nature of natural history. Princeton University Press, Princeton. 
Brunton, D. F. 1986. Additions to the Documentation of the Publication History of The Canadian Field-Naturalist and its Predecessors. Canadian Field-Naturalist 100: 423-426.

Brunton, D. F. 2004. Origins and History of The Ottawa Field-Naturalists' Club. Canadian Field-Naturalist 118: 138.

Bury, R. B. 2006. Natural history, field ecology, conservation biology, and wildlife management: Time to reconnect the dots. Herpetological Conservation and Biology 1: 56-61.

Carter, B. 2004. A Tribute to Thomas Henry Manning 19111998. The Canadian Field-Naturalist 118: 618-625.

Dayton, P. K., and E. Sala. 2001. Natural history: the sense of wonder, creativity and progress in ecology. Scientia Marina 65: 199-206.

Fleischner, T. L. 2005. Natural History and the Deep Roots of Resource Management. Natural Resources Journal 45: $1-13$.

Futuyma, D. J. 1998. Wherefore and whither the naturalist. American Naturalist 151: 1-6.

Gardner, H. 1999. Intelligence Reframed: Multiple Intelligences for the $21^{\text {st }}$ Century. Basic Books. New York.

Greene, H. W. 1994. Systematics and natural history, foundations for understanding and conservation biology. American Zoologist 34: 48-56.
Greene, H. W., and J. B. Losos. 1988. Systematics, natural history and conservation. Bioscience 38: 458-462.

Halliday, A. 2001. Finance Committee, in Minutes of the $122^{\text {nd }}$ Annual Business Meeting of the The Ottawa FieldNaturalists' Club, 9 January 2001. The Canadian FieldNaturalist 115: 534.

Lopez, B. 2001. The naturalist. Orion. Autumn 2001: 3843.

Louv, R. 2005. Last child in the woods: saving our children from nature-deficit syndrome. Algonquin Books.

Mayr, E. 1982. The growth of biological thought, diversity, evolution, and inheritance. Belknap Press, Cambridge, Massachusetts.

Peters, R. H. 1980. From natural history to ecology. Perspectives in biology and Medicine 23: 191-203.

Noss, R. F. 1996. The Naturalists Are Dying Off. Conservation Biology 10: 1-3.

Schmidley, D. J. 2005. What is means to be a naturalist and the future of natural history at American Universities. Journal of Mammalogy 86: 449-456.

Sears, P. B. 1944. The future of the naturalist. American Naturalist 78: 43 - 53.

Wilcove, D. S., and T. Eisner. 2000. The impending extinction of natural history. Chronicle Review, Chronicle of Higher Education 47 (3): B24. 